Tong, Y., \& Serrasqueiro, Z. (2021). Predictions of failure and financial distress:

A study on Portuguese high and medium-high technology small and mid-sized

enterprises. Journal of International Studies, 14(2), 9-25. doi:10.14254/2071-

$8330.2021 / 14-2 / 1$

\title{
Predictions of failure and financial distress: A study on Portuguese high and medium-high technology small and mid- sized enterprises
}

\author{
Yehui Tong \\ School of Accounting, Nanjing University of Finance and Economics, \\ China \\ tongyyhb@163.com
}

ORCID 0000-0002-7805-9470

Zélia Serrasqueiro

Faculty of Human and Social Sciences, University of Beira Interior,

Portugal

zelia@ubi.pt

ORCID 0000-0003-1761-5426

Abstract. The main purpose of this paper is to find the differences in the impacts of financial factors on business failure and financial distress. Using the traditional logistic regression method, this paper studies the ability of financial indicators to predict business failure and financial distress of small and mid-sized enterprises in Portuguese high and medium-high technology manufacturing sectors. The research results show that: (1) differences between financially healthy firms and failed firms are more obvious than differences between financially healthy firms and financially distressed firms; (2) the accurate rate of failure prediction decreases with time prolonging (from one year to three years prior to the event), whereas that of financial distress prediction maintains stable at a relatively lower level; (3) profitability is the most important indicator, which is negatively related to the probability of both business failure and financial distress; (4) debt-related and liquidity-related factors (especially indebtedness and general liquidity) are also important in predicting business failure and financial distress. This paper enriches the research literature on the predictions of both business failure and financial distress.

Keywords: financial factors, business failure, financial distress, high and mediumhigh technology, small and mid-sized enterprises.

JEL Classification: M10, M40 


\section{INTRODUCTION}

Predicting future development and detecting possible failure are of great importance to firms in the dynamic economic environment, because improving the capacity to identify the risk of future financial distress could help businesses adjust their strategy and behavior to avoid financial distress and future bankruptcy, and could mitigate the costs of financial distress and business failure (Gepp \& Kumar, 2015; Kubičková \& Nulíček, 2016). The important meaning of distress and failure prediction is not just limited to the microeconomic level but also expands to the macroeconomic level; for example, failure or financial distress may negatively influence shareholders, managers, employees, customers, suppliers, financial institutions as well as other external investors, and even economy and society overall (Jackson \& Wood, 2013; Muñoz-Izquierdo et al., 2020). What is more, the global financial crisis and then economic recession since 2008 have made firms' short-run illiquidity and long-run distress as well as failure become pressing problems (Pervan et al., 2018). Therefore, this topic is widely and deeply studied by academia, business practitioners and managers (Apergis et al., 2019).

While there is a large number of studies on the prediction models of bankruptcy, predicting corporate financial distress is relatively less explored (Platt \& Platt, 2002). Here it is necessary to demonstrate the differences between bankruptcy and financial distress. Financial distress means financial problems but not in bankruptcy; at the same time, financial distress may result in bankruptcy (Achim et al., 2016; Pozzoli \& Paolone, 2016). Putting it another way, failing in part of financial obligations does not necessarily lead to a bankruptcy (Muñoz-Izquierdo et al., 2020); more precisely, financial distress represents potential probability of a bankruptcy (Omelka et al., 2013). Therefore, a firm's financial health (or financial condition) desires more research than its legal status (whether bankruptcy or not) from the perspective of prediction, according to Pervan et al. (2018). The research of Gupta et al. (2018a) also shows the existence of differences in the impacts of factors on predicting bankruptcy and financial distress. As for the financially distressed firms, for resolving distress, their solutions include (for instance) restructuring debts and renegotiating with creditors, selling part of their assets to repay debts, or investing in new profitable projects (Gupta et al., 2018b).

A particular case is small firms. They face difficulties while solving financial distress, since they have limited assets to liquidate and thus repay debts (Blanco et al., 2012; Quintiliani, 2017). As a result, high failure rate is observed among small and mid-sized enterprises (SMEs); and in Portugal, the same is observed among the firms in high and medium-high technology sectors (Succurro \& Mannarino, 2014). However, the importance of SMEs should not be neglected: as pointed out by Alessandrini et al. (2019), in the European Union, SMEs account for more than 99 percent of the total number of enterprises; and Portugal is ranked third within the European Union by the highest intensity of SMEs (94 SMEs per 1000 inhabitants). Regarding the firms in high and medium-high technology sectors, they contributed to about one fourth of the total sales in 2016 in Portuguese manufacturing industry according to the CaixaBank Research as reported by Pinheiro (2019).

Therefore, following the study of Hill et al. (1996) that examined the prediction of financial and accounting ratios on firm's failure and financial distress, this paper studies financially influential factors for the failure and financial distress of Portuguese SMEs in high and medium-high technology sectors. Because the research on SMEs' failure prediction is not well developed yet (Andreeva et al., 2016), this paper firstly enriches the prediction studies on both SMEs' failure and financial distress (particularly in the high and medium-high technology sectors). Secondly, because one prediction model would not work well in different national environments and different economic periods, it is necessary to develop prediction models for specific national conditions and a particular time period (Gregova et al., 2020); thus, this paper 
contributes to the development of prediction models for Portugal during the period of the post European Sovereign Debt Crisis.

The remainder of this paper is structured as follows. Section 2 reviews the history of the prediction models development. Section 3 describes the sample data, definitions of variables, and methodology employed. Section 4 presents the empirical results and a brief discussion of these results. Section 5 concludes the paper.

\section{LITERATURE REVIEW}

Since the seminal research of Beaver (1966) and Altman (1968) on developing failure prediction models, plenty of researchers have focused on this topic from the perspective of empirical studies (Pervan et al., 2018; Šarlija \& Jeger, 2011); however, a lack of sufficient theoretical studies on insolvency prediction results in the problems of arbitrariness in selecting variables and modeling methods (Jackson and Wood, 2013). As for empirical models, improving prediction accuracy is a crucial target of investigations (Omelka et al., 2013); and Muñoz-Izquierdo et al. (2020) summarized three main ways to enhance the accuracy of financial distress prediction: selecting better financial ratios; developing prediction models; adding market variables and non-financial variables into predictions. As for SMEs, most are privately held and not listed on stock markets; thus, as pointed out by Altman et al. (2017), only accounting data (rather than market data) are available. In addition, according to Agarwal and Taffler (2008), the market-based approach does not perform better than the accounting-based approach in predictive accuracy.

Financial approach is an important method in bankruptcy prediction, since balance sheets and income statements proffer important information for early warning (Adamowicz \& Noga, 2018; Cultrera \& Brédart, 2016). Financial analysis is the basis for failure and financial distress prediction, as it can reveal the financial stability and strengths as well as weaknesses of firms (Gregova et al., 2020); thereby, financial ratios (representing solvency, activity, profitability, investment, and leverage) are the most frequently used variables in predictions (Fejér-Király, 2015; Šarlija \& Jeger, 2011). As for SMEs, because debts play a crucial role in external financing, they show higher credit and operational risks (Andrikopoulos \& Khorasgani, 2018; Gupta et al., 2018a). In fact, as stated by Quintiliani (2017), small firms are more likely to incur financial distress shown as cash shortages and few revenues; thus many researchers (such as, Calabrese et al. (2016), Gupta et al. (2018b), and Oliveira et al. (2017)) focus on the distress and failure predictions of SMEs. The information of approaching distress is also significant for SME managers to solve potential problems and works as a warning of possible future bankruptcy (Platt \& Platt, 2002).

In terms of prediction methods, as summarized by Yazdanfar and Nilsson (2008) as well as Jackson \& Wood (2013), the development of bankruptcy research can be classified into three stages: in the first stage, multiple discriminant analysis worked as the main statistical tool in late 1960s and 1970s after the research of Beaver (1966) and Altman (1968), which attempts to "classify the statistical units (objects) into two or more pre-defined groups" (Omelka et al., 2013, p. 2588); in the second stage, logit and probit models as the representative of conditional probability models have been developed by Ohlson (1980) and Zmijewski (1984) since 1980s ; in the third stage, with the development of computer technology, artificial neural networks as the representative method of data mining and machine learning techniques have started to be used in bankruptcy research since 1990s, which assume non-linearity of financial distress function (Malakauskas \& Lakstutiene, 2021; Mselmi et al., 2017).

Although many prediction techniques are used in failure prediction models with financial approach, discriminate analysis and logistic regression are the two methods used most (Cultrera \& Brédart, 2016). Regarding multivariate discriminant analysis, the classification between the two groups (healthy and bankrupt companies) is based on companies' financial characteristics, where a discriminant score is 
calculated for classifying of the two groups of companies (Fejér-Király, 2015). An important requirement for using multiple discriminant analysis models is that data should follow normal distribution, but this requirement usually cannot be fulfilled when using financial data and ratios; by contrast, logistic models are less constrained by distributional assumptions (Yazdanfar \& Nilsson, 2008). Mselmi et al. (2017) point out that: based on odd ratios, the coefficients in the results of logistic model can be easily interpreted, and for logistic models it is not required to assume homoscedasticity for independent variables. Multivariate discriminant analysis and logistic analysis belong to parametric models, while artificial neural networks belong to non-parametric models; in particular, artificial neural networks build non-linear relationships between variables, which could cause difficulties in explanation on causal relationships among the variables (Fejér-Király, 2015).

\section{DATA, VARIABLES AND METHODOLOGY}

The firms in the sample are chosen from the Iberian Balance Sheet Analysis System (SABI; developed by Bureau Van Dijk) database. In particular, the Portuguese small and mid-sized enterprises in the high technology and medium-high technology manufacturing sectors that report operating revenues in 2013, 2014, and 2015 to SABI database are chosen for creating the sample. Furthermore, each firm is tracked for five years (from 2013 to 2017), no matter whether it reports operating revenues in 2016 and 2017. The purpose of this sampling design is to observe the impacts of financial data that are respectively one year, two years and three years before the failure or financial distress events in the prediction models, which refers to the research design of Yazdanfar and Nilsson (2008). Here, according to the criteria of the European Union, SME is defined as: number of employees less than 250; and turnover less than or equal to 50 million Euros or balance sheet total less than or equal to 43 million Euros.

Because the purpose of this paper is to find similarities and differences of the influential factors in the failure and financial distress of Portuguese SMEs in high and medium-high technology sectors, the first work is to classify the firms in the sample into failed firms, financially distressed firms, and financially healthy firms (shown in Table 1). With regard to financial distress, as pointed out by Hill et al. (1996), financially distressed firms are the surviving firms and most financially distressed firms do not go bankruptcy. Traditionally financial distress is closely related to firm's capital structure (Gupta et al., 2018b), and compared to healthy firms financially distressed firms should have higher leverage and tend to show decreasing or negative net worth (Blanco et al., 2012).

Thus, this paper follows the method of Quintiliani (2017, p. 71-72) in identifying financially distressed firms: that is, "we consider as financial distress companies those that meet some of the following conditions: (i) its earnings before interest and taxes depreciation and amortization (EBITDA) are lower than its financial expenses for two consecutive years; and/or (ii) increase in the debt-to-net worth formula for two consecutive periods with concomitant decrease of the denominator." In particular, the above cited two conditions are observed in 2016 and 2017 for identifying financial distress event, while the data in 2015, 2014, and 2013 are used for predicting the probability of event.

Similar to the study of Pacheco (2015) in which the sampled firms from SABI database are classified into active and inactive groups, this paper chooses financially healthy firms from the firms labeled as "active" and failed firms from the firms that are not "active" firms in SABI database. In addition, financially healthy firms must report operating revenues in all the observed five years (from 2013 to 2017), while failed firms (reporting operating revenues in 2013, 2014 and 2015) must not report operating revenues in 2016 and 2017, which refers to the classifying method of Mata and Portugal (1994) in identifying failure. Here, now that low EBITDA (compared to financial expenses), increase in debt ratio, and decrease in net worth are seen as exerting negative impacts on financial health of firms, financially 
healthy firms are further identified from the "active" firms as those with high EBITDA (compared to financial expenses), decrease in debt ratio, and increase in net worth.

Table 1

Distribution of the sample firms in industry sectors

\begin{tabular}{|c|l|c|c|c|c|}
\hline $\begin{array}{c}\text { NACE } \\
\text { Rev.2 (2- } \\
\text { digit level) }\end{array}$ & \multicolumn{1}{|c|}{ Manufacturing sectors } & $\begin{array}{c}\text { Technology } \\
\text { type }\end{array}$ & $\begin{array}{c}\text { Number of } \\
\text { financially } \\
\text { healthy firm }\end{array}$ & $\begin{array}{c}\text { Number of } \\
\text { failed firm }\end{array}$ & $\begin{array}{c}\text { Number of } \\
\text { financially } \\
\text { distressed firm }\end{array}$ \\
\hline 20 & $\begin{array}{l}\text { Manufacture of chemicals } \\
\text { and chemical products }\end{array}$ & $\begin{array}{c}\text { Medium-high } \\
\text { technology }\end{array}$ & 40 & 9 & 15 \\
\hline 21 & $\begin{array}{l}\text { Manufacture of basic } \\
\text { pharmaceutical products and } \\
\text { pharmaceutical preparations }\end{array}$ & $\begin{array}{c}\text { High } \\
\text { technology }\end{array}$ & 3 & 2 & 1 \\
\hline 26 & $\begin{array}{l}\text { Manufacture of computer, } \\
\text { electronic and optical } \\
\text { products }\end{array}$ & $\begin{array}{c}\text { High } \\
\text { technology }\end{array}$ & 12 & 6 & 5 \\
\hline 27 & $\begin{array}{l}\text { Manufacture of electrical } \\
\text { equipment }\end{array}$ & $\begin{array}{c}\text { Medium-high } \\
\text { technology }\end{array}$ & 30 & 11 & 21 \\
\hline 29 & $\begin{array}{l}\text { Manufacture of machinery } \\
\text { and equipment n.e.c. }\end{array}$ & $\begin{array}{c}\text { Medium-high } \\
\text { technology }\end{array}$ & 74 & 2 & 8 \\
\hline 30 & $\begin{array}{l}\text { Manufacture of motor } \\
\text { vehicles, trailers and semi- } \\
\text { trailers }\end{array}$ & $\begin{array}{c}\text { Medium-high } \\
\text { technology }\end{array}$ & 25 & 6 & 3 \\
\hline
\end{tabular}

Notes: The technology type is referred to the high-tech classification of manufacturing industries based on NACERev. 2 2-digit level from the Eurostat.

Source: own compilation.

In terms of the independent variables or predictors (shown in Table 2), Kubíčková and Nulíček (2016) identified five groups of indicators for predicting financial distress and bankruptcy: efficiency, financial structure, liquidity, debt coverage, and activity. Thus, we use the ratio of earnings before interests and taxes (EBIT) to operating revenues (a proxy of profitability) to mirror efficiency, the ratio of current assets to current liabilities to represent liquidity, indebtedness to show debt coverage, and assets rotation to reflect activity. In addition, the proportion of tangible fixed assets to total assets and the proportion of current liabilities to total liabilities are also employed to show financial structure (asset structure and liability structure). Particularly, considering that the research target is the SMEs in high and medium-high technology sectors where intangible assets play an important role (Elston \& Audretsch, 2011) and at the same time many firms in the sample do not report intangible assets, a dummy variable for identifying whether a firm has intangible assets is created. Firm size (represented by total assets) as a crucial factor impacting on the performance of SMEs is also included (Gupta et al., 2018a).

Following the research method of Succurro and Mannarino (2014), logistic regression is used for identifying the predicting capacity of financial factors on the failure and financial distress of sample firms. As stated by Gupta et al. (2018a), since Ohlson (1980) introducing logistic regression into prediction models, this regression technique is commonly used. Logistic regression uses the logistic cumulative probability function in predicting models (Yazdanfar \& Nilsson, 2008). In particular, Tascón and Castaño (2017, p. 60) state that: "The binary logistic regression (binary logit) is a regression analysis in which the dependent variable takes values in the interval $[0,1]$ to indicate the probability of group membership; e.g., that of healthy firms or that of failed firms." 
Variable definitions

\begin{tabular}{|c|c|}
\hline $\begin{array}{l}\text { Dependent variable } \\
\text { (1): failure or financial } \\
\text { health }\end{array}$ & $\begin{array}{l}\text { Failed firms are the "inactive" firms that report operating revenues in 2013, 2014, and } 2015 \\
\text { but not report operating revenues in } 2016 \text { and } 2017 \text {. } \\
\text { Financially healthy firms are the "active" firms with high EBITDA (compared to financial } \\
\text { expenses), continuous decrease in debt ratio, and continuous increase in net worth from } \\
2013 \text { to } 2017 \text {. } \\
\text { Note: failed firms only report operating revenues in } 2013,2014 \text {, and } 2015 \text {, while financially } \\
\text { healthy firms report operating revenues in all the five years from } 2013 \text { to } 2017 \text {. }\end{array}$ \\
\hline $\begin{array}{l}\text { Dependent variable } \\
\text { (2): financial distress } \\
\text { or financial health }\end{array}$ & $\begin{array}{l}\text { Financially distressed firms are those that meet some of the following conditions: (i) its } \\
\text { earnings before interest and taxes depreciation and amortization (EBITDA) are lower than } \\
\text { its financial expenses in both } 2016 \text { and } 2017 \text {; and/or (ii) increase in the debt-to-net worth } \\
\text { formula from } 2016 \text { to } 2017 \text { with concomitant decrease of the denominator; and these } \\
\text { conditions do not appear in } 2013,2014 \text {, and } 2015 \text { (based on the classifying method of } \\
\text { Quintiliani (2017)). } \\
\text { Financially healthy firms are the "active" firms with high EBITDA (compared to financial } \\
\text { expenses), continuous decrease in debt ratio, and continuous increase in net worth from } \\
2013 \text { to } 2017 \text {. } \\
\text { Note: both the financially distressed firms and financially healthy firms must report } \\
\text { operating revenues in all the five years from } 2013 \text { to } 2017 \text {. }\end{array}$ \\
\hline \multicolumn{2}{|l|}{ Independent variables } \\
\hline Firm size & Natural logarithm of total assets (in thousands of Euros): Ln total asset \\
\hline Liquidity & General liquidity (current ratio): the ratio of current assets to current liabilities \\
\hline Solvency (leverage) & $\begin{array}{l}\text { Indebtedness: (Total shareholders funds and liabilities - Shareholders equity)/Total } \\
\text { shareholders funds and liabilities }\end{array}$ \\
\hline Intangibles & $\begin{array}{l}\text { Dummy variable of intangible assets (if firm's intangible assets are more than zero, it equals } \\
1 \text {; if not, it equals } 0 \text { ) }\end{array}$ \\
\hline Tangibles & The ratio of tangible fixed assets to total assets \\
\hline $\begin{array}{l}\text { Assets rotation } \\
\text { (activity) }\end{array}$ & The ratio of sales to total assets \\
\hline Profitability & The ratio of earnings before interest and taxes (EBIT) to operating revenues \\
\hline Liability structure & The ratio of current liabilities to total liabilities \\
\hline
\end{tabular}

Source: own compilation.

Here the data in 2013, 2014, and 2015 are respectively put into the regressions of the failure group (for comparing financially healthy firms with failed firms) and the financial distress group (for comparing financially healthy firms with financially distressed firms).

\section{REGRESSION RESULTS AND DISCUSSION}

\subsection{Univariate logistic regressions and multilinearity tests on independent variables}

According to Charitou et al. (2004), a univariate logistic regression should be used to identify the statistical significance of independent variables, where the variables are put into the logistic model one after another. As shown in Table 3 and 4, all the variables show statistical significance at least one year in the failure group except for the proportion of current liabilities to total liabilities, whereas there are four variables showing statistical significance (liquidity, intangibles, profitability, and the proportion of current liabilities to total liabilities) in the financial distress group. Given that the purpose of this paper is to 
observe the differences of the ability in predictors between distress and failure prediction, we believe that all the variables should be put into the (multivariate) logistic model, because every variable shows statistical significance in the univariate logistic model in either the failure or distress group.

Table 3

The results of the univariate logistic regression for the failure group (including failed and healthy firms)

\begin{tabular}{|c|c|c|c|c|c|c|}
\hline \multirow[b]{2}{*}{ Independent variables } & \multicolumn{2}{|c|}{2015} & \multicolumn{2}{|c|}{2014} & \multicolumn{2}{|c|}{2013} \\
\hline & Coefficient & $\mathrm{P}>|\mathrm{z}|$ & Coefficient & $\mathrm{P}>|\mathrm{z}|$ & Coefficient & $\mathrm{P}>|\mathrm{z}|$ \\
\hline Ln assets & $-0.683 * * *$ & 0.000 & $-0.582 * * *$ & 0.000 & $-0.508 * * *$ & 0.000 \\
\hline Liquidity & $0.064 * *$ & 0.048 & 0.066 & 0.139 & $0.131 * * *$ & 0.008 \\
\hline Indebtedness & $2.008 * * *$ & 0.000 & $1.002 * * *$ & 0.001 & $0.455 * *$ & 0.017 \\
\hline Intangibles & $-1.335 * * *$ & 0.004 & $-0.829 * *$ & 0.039 & $-0.641 *$ & 0.089 \\
\hline Tangibles & $-3.971 * * *$ & 0.001 & $-2.651 * * *$ & 0.007 & $-2.774 * * *$ & 0.005 \\
\hline Sales to assets & 0.077 & 0.185 & 0.143 & 0.139 & $0.218 * *$ & 0.032 \\
\hline Profitability & $-9.082 * * *$ & 0.000 & $-11.025 * * *$ & 0.000 & $-6.891 * * *$ & 0.000 \\
\hline Current liabilities & -0.274 & 0.632 & -0.623 & 0.282 & -0.468 & 0.410 \\
\hline
\end{tabular}

Notes: $*$ indicates significance level at 0.10 level, ** indicates significance level at 0.05 level, *** indicates significance level at 0.01 level.

Source: own calculation.

Table 4

The results of the univariate logistic regression for the financial distress group (including financially distressed and healthy firms)

\begin{tabular}{|l|c|c|c|c|c|c|}
\hline \multirow{2}{*}{ Independent variables } & \multicolumn{2}{|c|}{2015} & \multicolumn{2}{c|}{2014} & \multicolumn{2}{c|}{2013} \\
\cline { 2 - 7 } & Coefficient & $\mathrm{P}>|\mathrm{z}|$ & Coefficient & $\mathrm{P}>|\mathrm{z}|$ & Coefficient & $\mathrm{P}>|\mathrm{z}|$ \\
\hline Ln assets & -0.115 & 0.222 & -0.104 & 0.265 & -0.101 & 0.277 \\
\hline Liquidity & 0.039 & 0.164 & $\mathbf{0 . 0 3 5 *}$ & 0.099 & $\mathbf{0 . 0 6 1 *}$ & 0.090 \\
\hline Indebtedness & 0.544 & 0.203 & 0.432 & 0.230 & -0.053 & 0.851 \\
\hline Intangibles & $\mathbf{- 0 . 6 2 8 *}$ & 0.065 & -0.427 & 0.194 & -0.412 & 0.203 \\
\hline Tangibles & -0.300 & 0.683 & -0.216 & 0.762 & -0.081 & 0.909 \\
\hline Sales to assets & -0.076 & 0.631 & 0.011 & 0.948 & -0.061 & 0.729 \\
\hline Profitability & $\mathbf{- 1 7 . 2 7 7 * * * *}$ & 0.000 & $\mathbf{- 7 . 4 2 3 * * *}$ & 0.000 & $\mathbf{- 7 . 5 9 0 * * *}$ & 0.002 \\
\hline Current liabilities & -0.119 & 0.827 & 0.171 & 0.759 & 0.968 & $\mathbf{0 . 0 9 8 *}$ \\
\hline
\end{tabular}

Notes: $*$ indicates significance level at 0.10 level, ** indicates significance level at 0.05 level, *** indicates significance level at 0.01 level.

Source: own calculation.

When doing (multivariate) logistic analysis, multilinearity problem should be noticed (Giacosa et al, 2016). Table 5 and 6 present the Pearson Correlation coefficients of the independent variables separately for the failure group (including failed firms and healthy firms) and the distress group (including distressed firms and healthy firms), where no coefficient's absolute value is greater than 0.7 ; thus, illustrating no serious collinearity problems. 
Table 5

Pearson correlation coefficients of the independent variables for the failure group (including failed and healthy firms)

\begin{tabular}{|c|c|c|c|c|c|c|c|c|}
\hline 2015 & $\begin{array}{c}\mathrm{Ln} \\
\text { assets }\end{array}$ & Liquidity & Indebtedness & $\begin{array}{l}\text { Intangibles( } \\
\text { Dummy) }\end{array}$ & Tangibles & $\begin{array}{c}\text { Sales to } \\
\text { assets }\end{array}$ & Profitability & $\begin{array}{c}\text { Current } \\
\text { liabilities }\end{array}$ \\
\hline Ln assets & 1 & & & & & & & \\
\hline Liquidity & -0.034 & 1 & & & & & & \\
\hline Indebtedness & -0.463 & -0.122 & 1 & & & & & \\
\hline Intangibles & 0.441 & -0.134 & -0.091 & 1 & & & & \\
\hline Tangibles & 0.362 & -0.202 & -0.163 & 0.220 & 1 & & & \\
\hline $\begin{array}{l}\text { Sales to } \\
\text { assets }\end{array}$ & -0.262 & -0.058 & 0.541 & -0.056 & -0.101 & 1 & & \\
\hline Profitability & 0.128 & 0.099 & -0.288 & 0.094 & 0.071 & 0.001 & 1 & \\
\hline Cur. liabilities & 0.049 & -0.252 & -0.007 & -0.004 & -0.269 & 0.103 & 0.033 & 1 \\
\hline 2014 & $\begin{array}{c}\text { Ln } \\
\text { assets }\end{array}$ & Liquidity & Indebtedness & $\begin{array}{c}\text { Intangibles } \\
\text { (Dummy) }\end{array}$ & Tangibles & $\begin{array}{l}\text { Sale to } \\
\text { assets }\end{array}$ & Profitability & $\begin{array}{c}\text { Current } \\
\text { liabilities }\end{array}$ \\
\hline Ln assets & 1 & & & & & & & \\
\hline Liquidity & -0.006 & 1 & & & & & & \\
\hline Indebtedness & -0.338 & -0.191 & 1 & & & & & \\
\hline Intangibles & 0.458 & -0.060 & -0.098 & 1 & & & & \\
\hline Tangibles & 0.297 & -0.213 & -0.135 & 0.143 & 1 & & & \\
\hline $\begin{array}{l}\text { Sales to } \\
\text { assets }\end{array}$ & -0.340 & -0.117 & 0.079 & -0.111 & -0.210 & 1 & & \\
\hline Profitability & 0.172 & 0.076 & -0.222 & 0.058 & 0.079 & 0.033 & 1 & \\
\hline Cur. liabilities & 0.028 & -0.325 & -0.047 & -0.011 & -0.355 & 0.188 & -0.023 & 1 \\
\hline 2013 & $\begin{array}{c}\text { Ln } \\
\text { assets }\end{array}$ & Liquidity & Indebtedness & $\begin{array}{c}\text { Intangibles } \\
\text { (Dummy) }\end{array}$ & Tangibles & $\begin{array}{c}\text { Sales to } \\
\text { assets }\end{array}$ & Profitability & $\begin{array}{l}\text { Current } \\
\text { liabilities }\end{array}$ \\
\hline Ln assets & 1 & & & & & & & \\
\hline Liquidity & -0.015 & 1 & & & & & & \\
\hline Indebtedness & -0.400 & -0.094 & 1 & & & & & \\
\hline Intangibles & 0.462 & -0.046 & -0.106 & 1 & & & & \\
\hline Tangibles & 0.308 & -0.201 & -0.143 & 0.146 & 1 & & & \\
\hline $\begin{array}{l}\text { Sales to } \\
\text { assets }\end{array}$ & -0.480 & -0.152 & 0.557 & -0.139 & -0.235 & 1 & & \\
\hline Profitability & 0.208 & -0.253 & -0.490 & 0.028 & 0.134 & -0.149 & 1 & \\
\hline Cur. liabilities & -0.017 & -0.326 & 0.035 & -0.036 & -0.390 & 0.192 & 0.084 & 1 \\
\hline
\end{tabular}

Notes: The number of failed firms is 46, and the number of financially healthy firms is 190; so totally there are 236 firms in the failure group. Because the failure event causes failed firms not reporting data in 2016 and 2017, only the data in 2013, 2014 and 2015 are tested by Pearson here.

Source: own calculation. 
Table 6

Pearson correlation coefficients of the independent variables for the financial distress group (including financially distressed and healthy firms)

\begin{tabular}{|c|c|c|c|c|c|c|c|c|}
\hline 2017 & Ln assets & Liquidity & $\begin{array}{l}\text { Indebt } \\
\text { edness }\end{array}$ & $\begin{array}{c}\text { Intangibles } \\
\text { (Dummy) }\end{array}$ & Tangibles & $\begin{array}{c}\begin{array}{c}\text { Sales to } \\
\text { assets }\end{array} \\
\end{array}$ & Profitability & $\begin{array}{r}\text { Current } \\
\text { liabilities } \\
\end{array}$ \\
\hline Ln assets & 1 & & & & & & & \\
\hline Liquidity & -0.156 & 1 & & & & & & \\
\hline Indebtedness & -0.271 & -0.239 & 1 & & & & & \\
\hline Intangibles & 0.521 & -0.101 & -0.093 & 1 & & & & \\
\hline Tangibles & 0.246 & -0.164 & 0.045 & 0.129 & 1 & & & \\
\hline Sales to assets & -0.308 & -0.113 & 0.165 & -0.036 & -0.252 & 1 & & \\
\hline Profitability & 0.273 & -0.683 & -0.236 & 0.104 & -0.010 & 0.106 & 1 & \\
\hline Cur. liabilities & 0.117 & -0.006 & -0.225 & 0.011 & -0.137 & 0.004 & -0.008 & 1 \\
\hline 2016 & Ln assets & Liquidity & $\begin{array}{l}\text { Indebt } \\
\text { edness }\end{array}$ & $\begin{array}{c}\text { Intangibles } \\
\text { (Dummy) }\end{array}$ & Tangibles & $\begin{array}{c}\text { Sales to } \\
\text { assets }\end{array}$ & Profitability & $\begin{array}{c}\text { Current } \\
\text { liabilities }\end{array}$ \\
\hline Ln assets & 1 & & & & & & & \\
\hline Liquidity & -0.151 & 1 & & & & & & \\
\hline Indebtedness & -0.257 & -0.248 & 1 & & & & & \\
\hline Intangibles & 0.524 & -0.098 & -0.071 & 1 & & & & \\
\hline Tangibles & 0.253 & -0.168 & 0.016 & 0.143 & 1 & & & \\
\hline Sale to assets & -0.247 & -0.114 & 0.098 & -0.019 & -0.263 & 1 & & \\
\hline Profitability & 0.239 & -0.322 & -0.209 & 0.109 & -0.056 & 0.081 & 1 & \\
\hline Cur. liabilities & 0.076 & -0.017 & -0.195 & 0.017 & -0.203 & 0.130 & 0.056 & 1 \\
\hline 2015 & Ln assets & Liquidity & $\begin{array}{l}\text { Indebt } \\
\text { edness }\end{array}$ & $\begin{array}{c}\text { Intangibles } \\
\text { (Dummy) }\end{array}$ & Tangibles & $\begin{array}{c}\begin{array}{c}\text { Sales to } \\
\text { assets }\end{array} \\
\end{array}$ & Profitability & $\begin{array}{c}\text { Current } \\
\text { liabilities } \\
\end{array}$ \\
\hline Ln assets & 1 & & & & & & & \\
\hline Liquidity & -0.146 & 1 & & & & & & \\
\hline Indebtedness & -0.279 & -0.303 & 1 & & & & & \\
\hline Intangibles & 0.461 & -0.109 & -0.036 & 1 & & & & \\
\hline Tangibles & 0.269 & -0.196 & -0.028 & 0.151 & 1 & & & \\
\hline Sales to assets & -0.199 & -0.102 & 0.150 & -0.049 & -0.226 & 1 & & \\
\hline Profitability & 0.046 & 0.023 & -0.065 & -0.101 & -0.139 & -0.063 & 1 & \\
\hline Cur. Liabilities & 0.060 & -0.082 & -0.149 & 0.003 & -0.213 & 0.144 & 0.021 & 1 \\
\hline 2014 & Ln assets & Liquidity & $\begin{array}{l}\text { Indebt } \\
\text { edness }\end{array}$ & $\begin{array}{c}\text { Intangibles } \\
\text { (Dummy) }\end{array}$ & Tangibles & $\begin{array}{c}\begin{array}{c}\text { Sale to } \\
\text { assets }\end{array} \\
\end{array}$ & Profitability & $\begin{array}{c}\text { Current } \\
\text { liabilities } \\
\end{array}$ \\
\hline Ln assets & 1 & & & & & & & \\
\hline Liquidity & -0.043 & 1 & & & & & & \\
\hline Indebtedness & -0.310 & -0.147 & 1 & & & & & \\
\hline Intangibles & 0.463 & -0.077 & -0.131 & 1 & & & & \\
\hline Tangibles & 0.238 & -0.003 & -0.026 & 0.109 & 1 & & & \\
\hline Sales to assets & -0.300 & -0.131 & 0.197 & -0.144 & -0.271 & 1 & & \\
\hline Profitability & 0.107 & -0.227 & -0.165 & 0.081 & -0.124 & -0.040 & 1 & \\
\hline Cur. liabilities & 0.014 & -0.185 & -0.162 & 0.018 & -0.314 & 0.174 & 0.102 & 1 \\
\hline
\end{tabular}




\begin{tabular}{|l|c|c|c|c|c|c|c|c|}
\hline \multicolumn{1}{|c|}{2013} & Ln assets & Liquidity & $\begin{array}{c}\text { Indebt } \\
\text { edness }\end{array}$ & $\begin{array}{c}\text { Intangibles } \\
\text { (Dummy) }\end{array}$ & Tangibles & $\begin{array}{c}\text { Sales to } \\
\text { assets }\end{array}$ & Profitability & $\begin{array}{c}\text { Current } \\
\text { liabilities }\end{array}$ \\
\hline Ln assets & 1 & & & & & & & \\
\hline Liquidity & -0.038 & 1 & & & & & & \\
\hline Indebtedness & -0.344 & -0.242 & 1 & & & & & \\
\hline Intangibles & 0.469 & -0.030 & -0.130 & 1 & & & & \\
\hline Tangibles & 0.221 & -0.083 & -0.015 & 0.128 & 1 & & & \\
\hline Sales to assets & -0.282 & -0.153 & 0.312 & -0.124 & -0.262 & 1 & & \\
\hline Profitability & 0.071 & -0.046 & -0.113 & 0.092 & -0.204 & -0.006 & 1 & \\
\hline Cur. liabilities & 0.033 & -0.202 & -0.135 & 0.014 & -0.355 & 0.196 & 0.118 & 1 \\
\hline
\end{tabular}

Notes: The number of financially distressed firms is 60, and the number of financially healthy firms is 190; so totally there are 250 firms in the financial distress group. Because both the distressed firms and healthy firms show data from 2013 to 2017, Pearson tests include all the five-year data.

Source: own calculation.

\subsection{The results of logistic regression for the failure group}

The following three paragraphs show the results of logistic regression for the failure group at the statistically significant level of 0.1 (shown in Table 7).

Table 7

Regression results for the failure group

\begin{tabular}{|c|c|c|c|c|c|c|}
\hline \multirow{6}{*}{$\begin{array}{l}\text { Dependent } \\
\text { variable: failure or } \\
\text { not; } \\
\text { Number of firms: } \\
236 \text {; }\end{array}$} & \multicolumn{2}{|c|}{2015} & \multicolumn{2}{|c|}{2014} & \multicolumn{2}{|c|}{2013} \\
\hline & \multicolumn{2}{|c|}{ Classification accuracy: $94.92 \%$} & \multicolumn{2}{|c|}{ Classification accuracy: $89.41 \%$} & \multicolumn{2}{|c|}{ Classification accuracy: $86.02 \%$} \\
\hline & \multicolumn{2}{|c|}{ Log likelihood: -44.950 } & \multicolumn{2}{|c|}{ Log likelihood: $-\mathbf{- 7 3 . 9 9 0}$} & \multicolumn{2}{|c|}{ Log likelihood: -84.322} \\
\hline & \multicolumn{2}{|c|}{ LR chi2(8): 142.92} & \multicolumn{2}{|c|}{ LR chi2(8): 84.84} & \multicolumn{2}{|c|}{ LR chi2(8): 64.18} \\
\hline & \multicolumn{2}{|c|}{ Prob > chi2: 0.0000} & \multicolumn{2}{|c|}{ Prob > chi2: 0.0000} & \multicolumn{2}{|c|}{ Prob > chi2: 0.0000} \\
\hline & \multicolumn{2}{|c|}{ Pseudo R²: 0.614} & \multicolumn{2}{|c|}{ Pseudo $\mathrm{R}^{2}: 0.364$} & \multicolumn{2}{|c|}{ Pseudo R $2: 0.276$} \\
\hline $\begin{array}{l}\text { Independent } \\
\text { variables }\end{array}$ & Coefficients & $\mathrm{P}>|\mathrm{z}|$ & Coefficients & $\mathrm{P}>|\mathrm{z}|$ & Coefficients & $\mathrm{P}>|\mathrm{z}|$ \\
\hline Ln total asset & -0.362 & 0.157 & -0.282 & 0.120 & $-0.450 * *$ & 0.012 \\
\hline General liquidity & $0.289 * * *$ & 0.000 & $0.186 * * *$ & 0.007 & $0.251 * * *$ & 0.002 \\
\hline Indebtedness & $1.684 * * *$ & 0.001 & $0.532 *$ & 0.057 & 0.139 & 0.308 \\
\hline $\begin{array}{l}\text { Dummy variable } \\
\text { of intangible assets }\end{array}$ & -0.556 & 0.483 & -0.220 & 0.701 & -0.126 & 0.813 \\
\hline $\begin{array}{l}\text { Tangible assets to } \\
\text { total assets }\end{array}$ & -1.165 & 0.586 & -0.876 & 0.552 & 0.149 & 0.907 \\
\hline Sale to total assets & -0.045 & 0.524 & 0.030 & 0.760 & 0.031 & 0.816 \\
\hline $\begin{array}{l}\text { EBIT to operating } \\
\text { revenues }\end{array}$ & $-13.127 * * *$ & 0.000 & $-10.999 * * *$ & 0.000 & $-6.865 * * *$ & 0.001 \\
\hline $\begin{array}{l}\text { Current liabilities } \\
\text { to total liabilities }\end{array}$ & $2.506 * *$ & 0.037 & 0.789 & 0.419 & 0.415 & 0.618 \\
\hline Constant & -2.801 & 0.116 & -0.677 & 0.615 & 0.298 & 0.804 \\
\hline
\end{tabular}

Notes: * indicates significance level at 0.10 level, ** indicates significance level at 0.05 level, *** indicates significance level at 0.01 level.

Source: own calculation. 
Using the data of 2015 , the classification accuracy of the failure group is $94.92 \%$. There are four statistically significant variables at the significant level of 0.05 : general liquidity, indebtedness, the ratio of EBIT to operating revenues, and the ratio of current liabilities to total liabilities. In particular, the first three variables (general liquidity, indebtedness, and the ratio of EBIT to operating revenues) are at the statistically significant level of 0.01 , and the ratio of current liabilities to total liabilities is at the significant level between 0.01 and 0.05; general liquidity, indebtedness, and the ratio of current liabilities to total liabilities are positively related to the probability of failure, while the ratio of EBIT to operating revenues is negatively related to failure.

Using the data of 2014, the classification accuracy of the failure group is $89.41 \%$. Three variables are statistically significant: general liquidity, indebtedness, and the ratio of EBIT to operating revenues. Similar to the results of 2015, general liquidity and indebtedness are positively related to the probability of failure, while the ratio of EBIT to operating revenues is negatively related to failure; general liquidity and the ratio of EBIT to operating revenues are at the statistically significant level of 0.01 . The difference is that here indebtedness is at the statistically significant level between 0.05 and 0.1 .

Using the data of 2013, the classification accuracy of the failure group is $86.02 \%$. The three statistically significant variables here are the natural logarithm of total assets, general liquidity, and the ratio of EBIT to operating revenues. In concrete, general liquidity is positively related to the probability of failure, while the natural logarithm of total assets and the ratio of EBIT to operating revenues are negatively related to failure. Aside from the natural logarithm of total assets (at the significant level between 0.01 and 0.05 ), general liquidity and the ratio of EBIT to operating revenues are at the significant level of 0.01 .

\subsection{The results of logistic regression for the financial distress group}

The following two paragraphs show the results of logistic regression for the financial distress group at the statistically significant level of 0.1 (shown in Table 8). The classification accuracy of the financial distress group of 2015 is $79.20 \%$. The results of 2015 also show that: indebtedness (at the significant level between 0.05 and 0.1), the dummy variable of intangible assets (at the significant level between 0.01 and 0.05), and the ratio of EBIT to operating revenues (at the significant level of 0.01) are statistically significant variables. Similar to the results of the failure group, here indebtedness is positively related to the probability of financial distress, whereas the ratio of EBIT to operating revenues is negatively related to the probability of financial distress; in particular, the dummy variable of intangible assets is negatively related to the probability of financial distress.

The classification accuracy of the financial distress group of 2014 is $80.40 \%$, and the only statistically significant variable is the ratio of EBIT to operating revenues at the significant level of 0.01 (which is negatively related to the probability of financial distress). Similarly, in the logistic regression of the 2013 financial distress group, the classification accuracy is $79.60 \%$, and the ratio of EBIT to operating revenues (being negatively related to the probability of financial distress) is at the significant level of 0.01 . The difference is that the ratio of current liabilities to total liabilities is positively related to the probability of financial distress at the significant level between 0.01 and 0.05 . 
Regression results for the distress group

\begin{tabular}{|c|c|c|c|c|c|c|}
\hline \multirow{6}{*}{$\begin{array}{l}\text { Dependent } \\
\text { variable: distress } \\
\text { or not; } \\
\text { Number of firms: } \\
250 \text {; }\end{array}$} & \multicolumn{2}{|c|}{2015} & \multicolumn{2}{|c|}{2014} & \multicolumn{2}{|c|}{2013} \\
\hline & \multicolumn{2}{|c|}{ Classification accuracy: $79.20 \%$} & \multicolumn{2}{|c|}{ Classification accuracy: $80.40 \%$} & \multicolumn{2}{|c|}{ Classification accuracy: $79.60 \%$} \\
\hline & \multicolumn{2}{|c|}{ Log likelihood $=-111.357$} & \multicolumn{2}{|c|}{ Log likelihood $=-125.927$} & \multicolumn{2}{|c|}{ Log likelihood: -122.944 } \\
\hline & \multicolumn{2}{|c|}{ LR chi2(8): 52.83} & \multicolumn{2}{|c|}{ LR chi2(8): 23.69} & \multicolumn{2}{|c|}{ LR chi2(8): 29.65} \\
\hline & \multicolumn{2}{|c|}{ Prob > chi2: 0.0000} & \multicolumn{2}{|c|}{ Prob > chi2: 0.0026} & \multicolumn{2}{|c|}{ Prob > chi2: 0.0002} \\
\hline & \multicolumn{2}{|c|}{ Pseudo R²: 0.192} & \multicolumn{2}{|c|}{ Pseudo R2: 0.086} & \multicolumn{2}{|c|}{ Pseudo R2: 0.108} \\
\hline $\begin{array}{l}\text { Independent } \\
\text { variables }\end{array}$ & Coefficient & $\mathrm{P}>|\mathrm{z}|$ & Coefficients & $\mathrm{P}>|\mathrm{z}|$ & Coefficients & $\mathrm{P}>|\mathrm{z}|$ \\
\hline Ln total assets & 0.142 & 0.269 & 0.010 & 0.933 & -0.033 & 0.796 \\
\hline General liquidity & 0.053 & 0.201 & 0.042 & 0.290 & 0.085 & 0.115 \\
\hline Indebtedness & $0.963 *$ & 0.078 & 0.411 & 0.373 & 0.059 & 0.871 \\
\hline $\begin{array}{l}\text { Dummy intangible } \\
\text { assets }\end{array}$ & $-1.073 * *$ & 0.013 & -0.268 & 0.484 & -0.273 & 0.482 \\
\hline $\begin{array}{l}\text { Tangible assets to } \\
\text { total assets }\end{array}$ & -0.565 & 0.540 & -0.207 & 0.813 & 0.267 & 0.769 \\
\hline $\begin{array}{l}\text { Sales to total } \\
\text { assets }\end{array}$ & -0.198 & 0.260 & -0.074 & 0.697 & -0.178 & 0.384 \\
\hline $\begin{array}{l}\text { EBIT to operating } \\
\text { revenues }\end{array}$ & $-18.981 * * *$ & 0.000 & $-7.211 * * *$ & 0.001 & $-8.112 * * *$ & 0.003 \\
\hline $\begin{array}{l}\text { Current liabilities } \\
\text { to total liabilities }\end{array}$ & 0.352 & 0.574 & 0.708 & 0.288 & $1.724 * *$ & 0.014 \\
\hline Constant & -1.091 & 0.358 & -1.406 & 0.229 & -1.850 & 0.119 \\
\hline
\end{tabular}

Notes: * indicates significance level at 0.10 level, ** indicates significance level at 0.05 level, *** indicates significance level at 0.01 level.

Source: own calculation.

\subsection{Discussion}

Compared to the financial distress group, the failure group shows more statistically significant variables in every selected year; in addition, the accurate rates of classification are higher in the failure group. Thus, there are more differences between failed firms and financially healthy firms than between financially distressed firms and financially healthy firms. This result is of no surprise, because financial distress could be seen as the prior stage of a bankruptcy (Achim et al., 2016). A special finding is that: the accurate rate of failure prediction decreases with using the data away from the failure event in time, which is to some extent similar to the finding of Vavrina et al. (2013).

In terms of the detailed results, profitability-related variable (the ratio of EBIT to operating revenues) shows statistical significance in all the regressions in both the failure group and the financial distress group. In particular, the relationship between profitability and the probability of failure or financial distress is negative, and its statistical significance keeps at 0.01 level. So profitability is a very important indicator to both failure and financial distress, which works as a positive factor to firms. With regard to the negative relationship between profitability and failure, Gupta et al. (2018b) point out that: profitability is linked to failure through liquidity; specifically, poor profitability would cause fragile liquidity and then default on debt. Žiković (2018) too finds a negative relationship between profitability and the probability 
of distress; and it is explained that the firms with high profitability could have more internally generated funds, thus relying less on borrowing and then having lower expenditures for liabilities.

General liquidity serves as a statistically significant variable (at the significant level of 0.01) in all the regressions in the failure group, and the relationship between general liquidity and the probability of failure keeps positive (when being statistically significant). Similar to general liquidity, indebtedness also shows a positive relationship to the probability of failure when it is statistically significant in 2015 (one year before the failure event) and 2014 (two years before the failure event). Here, noteworthy is that the statistically significant level of indebtedness decreases from being less than 0.01 in 2015 to being between 0.05 and 0.1 in 2014; so prolonging time would reduce the ability of indebtedness in predicting failure. Indebtedness is also positively related to the probability of financial distress in 2015 at the significant level between 0.05 and 0.1 .

Compared to indebtedness or leverage (as the indicator of long-term financial obligation; Tascón \& Castaño, 2017), general liquidity or liquidity ratio (as the indicator of short-term economic financial equilibrium; Tascón \& Castaño, 2017) plays a more important role in the prediction of failure, because of not only showing statistical significance in more years but also showing higher statistically significant level. Both indebtedness and general liquidity are positively related to the probability of failure. The positive relationship between general liquidity and the probability of failure does not correspond to the theoretical expectation of liquidity (that is, as stated by Blanco et al. (2012), the ratio of current assets to current liabilities reflects firm's ability to repay its short-term debt with its short-term assets). However, high current ratio does not necessarily mean financial health; for instance, Hill et al. (1996) find a positive relationship between liquidity and financial distress.

Here the positive relationship between indebtedness and the probability of failure or financial distress corresponds to the finding of Andrikopoulos and Khorasgani (2018) that the ratio of total liabilities to total assets is negatively related to the probability of not defaulting. As pointed out by Gupta et al. (2018a), the ratio of total liabilities to total assets can be used as a measure of financial fragility; thus, higher leverage means being more financially fragile and should be easier to trigger financial problems and failure. Žiković (2018) too finds that leverage is positively related to the probability of distress, and it is interpreted as highly indebted firms needing to pay high interest costs and high expenditures for liabilities.

The proportion of current liabilities to total liabilities is positively related to the probability of failure in 2015 (one year before failure event) at the significant level between 0.01 and 0.05 , and it is also positively related to the probability of financial distress in 2013 (three years before financial distress) at the significant level between 0.01 and 0.05 . This result is to some extent close to the finding of Andrikopoulos and Khorasgani (2018) that the relationship between short-term debt and the probability of survival is negative. Thus, compared to short-term debt, long-term debt can benefit more to SMEs; and, because SMEs are usually financially constrained (Gupta et al., 2018b), the difficulties for SMEs to get access to external financing could be the reasons that make long-term debt more important. Furthermore, as for high and medium-high technology SMEs, long-term debt (compared to short-term debt) should be more suitable for the activities in research and development.

Total assets only show statistical significance (at the significant level between 0.01 and 0.05 ) in the 2013 failure group with a negative relationship to failure. Similarly, Pérez et al. (2004) also confirm that large firms are advantageous in survival compared to small firms. In fact, many empirical studies support the positive effect of size on survival (Görg \& Strobl, 2003). This means that firm size (represented by the natural logarithm of total assets) is a positive factor to firms. Audretsch and Mahmood (1995) further point out the reason that the difference between firm size and industry minimum efficient scale gives rise to cost disadvantage. 
The dummy variable of intangible assets only shows statistical significance (at the significant level between 0.01 and 0.05 ) in the 2015 financial distress group with a negative relationship to the probability of distress. This finding is to some extent similar to the findings of Quintiliani (2017) regarding a negative relationship between invisible intangible assets and expected financial distress costs as well as a positive relationship between financial distress likelihood and expected financial distress costs in SMEs. Intangible assets serve as a positive factor to firms, and its positive impact on the firms in financial distress group may be based on the continuity of operation. The main difference between financially distressed firms and failed firms here is that: financially distressed firms maintain operating even if incurring financial problems, whereas failed firms do not generate operating revenues. So it is reasonable that the positive impact of intangible assets is shown in the financial distress group (where firms keep on operating), given that intangible assets represent firm's ability about long-term strategic logic and value oriented rather than short-run productivity and profitability (Chappell \& Jaffe, 2018; Quintiliani, 2017).

The ratio of tangible fixed assets to total assets and asset rotation are statistically insignificant in any regression. Although theoretically speaking the firms with more tangible assets should be easier to obtain external financing and refinancing in financial difficulties (Gupta et al., 2018a), the case of Portuguese high and medium-high technology SMEs may be different. In Portugal there are not so many firms in high and medium-high technology sectors, so the value of tangible fixed assets as collateral in these sectors is limited (which may further cause limitation on the capacity of these firms to obtain external financing). The result here may also reflect that tangible fixed assets are less important to the high and medium-high technology SMEs (if, for example, compared to intangible assets). The result that asset rotation works as an insignificant indicator is of no surprise, since it is not a factor directly relating to the cash for repaying debts (compared to profit and debt factors).

\section{CONCLUSION}

Following the studies on the prediction of bankruptcy and financial distress, this paper analyzes the financial indicators separately on the business failure and financial distress of Portuguese SMEs in high and medium-high technology sectors. The findings show that: (1) there are more statistically significant variables as indicators to predict business failure than to predict financial distress, so the differences between financially healthy firms and failed firms tend to be more manifest than the differences between financially healthy firms and financially distressed firms; (2) the classification accuracy of failure prediction is obviously higher than that of financial distress prediction, thus illustrating higher predictability of financial factors on business failure compared to on financial distress; (3) with time prolonging (from one year to three years before the failure or financial distress event), the classification accuracy of failure prediction decreases obviously while that of financial distress prediction generally keeps stable at a relatively lower level, which demonstrates higher stability in financial prediction of financial distress.

With regard to the detailed predictability of financial factors, profitability is the most important indicator on the probability of both business failure and financial distress not only because of being statistically significant in all the regressions but also due to showing significance less than 0.01 ; and good profitability can help firms avoid business failure and financial distress (which should be suitable for firms in any sector). As for debt-related factors, indebtedness and the ratio of current liabilities to total liabilities (representing debt maturity structure) are positively related to the probability of both business failure and financial distress (which illustrate the negative impact of high leverage and the positive impact of more long-term debts), and the predictability of indebtedness is stronger than that of debt maturity structure. Here, the negative impact of high indebtedness corresponds to the commonsense and the definition of Quintiliani (2017) for financial distress where an increase in indebtedness represents a decrease in financial 
health. On the other hand, the positive impact of long-term debts should be in accord to the features of high and medium-high technology SMEs, in which long-term investments supported by long-term debts can benefit much to the innovations as well as research and development of this kind of firms.

General liquidity is an important indicator in failure prediction, while its positive relationship to the probability of failure confirms the view of Blanco et al. (2012) - that is, high current ratio does not necessarily mean good financial health. In fact, high liquidity (or keeping large amount of liquid assets) may constrain the investments in long-term projects, and long-term investments (especially in research and development) should be of great importance in the realization of firms' value in high and mediumhigh technology sectors. Firm size and intangible assets are not as important as the previously mentioned indicators. Notwithstanding that, the positive impact of larger firm size corresponds to the traditional theory of efficient scale, while the positive effect taken by intangible assets to reduce the possibility of financial distress can reflect long-term benefits of intangibles to the SMEs in high and medium-high technology sectors based on going concern (because here both financially distressed and financially healthy firms keep on operating during the whole observing period).

All in all, this paper contributes to the mainstream research on the predictions of business failure and financial distress with the evidence of high and medium-high technology SMEs. In addition, the empirical studies on comparing the differences between failure and financial distress (the research field of which is relatively less explored compared to a huge literature on bankruptcy prediction) are also enriched by the results of this paper. Notwithstanding that, this paper is limited by the availability of data (that is, there are small numbers of failed and financially distressed firms in high and medium-high technology sectors in Portugal). Therefore, if data are available, future research may consider to compare different countries, which could not only enlarge the sample size but also obtain richer findings.

\section{ACKNOWLEDGEMENT}

Zélia Serrasqueiro would like to express acknowledge to the financial support of the research unit o CEFAGEUBI - sponsored by the FCT - Portuguese Foundation for the Development of Science and Technology, Ministry of Science, Technology and Higher Education and Science, project UIDB/04007/2020, respectively.

\section{REFERENCES}

Achim, M.V., Borlea, S.N., \& Găban, L.V. (2016). Failure prediction from the investors' view by using financial ratios. Lesson from Romania. E\&M Economics and Management, 19(4), 117-133. doi: 10.15240/tul/001/2016-4009

Adamowicz, K., \& Noga, T. (2018). Identification of financial ratios applicable in the construction of a prediction model for bankruptcy of wood industry enterprises. Folia Forestalia Polonica, Series A - Forestry, 60(1), 61-72. doi: 10.2478/ffp-2018-0006

Agarwal, V. \& Taffler, R. (2008). Comparing the performance of market-based and accounting-based bankruptcy prediction models. Journal of Banking \& Finance, 32(8), 1541-1551. doi: 10.1016/j.jbankfin.2007.07.014

Alessandrini, M., Valenza, A., Gramillano, A., Zingaretti, C., Zillmer, S., Holstein, F., Salvatori, G., Dallhammer, E., Gaupp-Berghausen, M., \& Derszniak M. (2019). EU policy framework on SMEs: state of play and challenges. https://cor.europa.eu/en/engage/studies/Documents/EU-SMEs/EU-policy-SMEs.pdf

Altman, E. (1968). Financial ratios, discriminant analysis and the prediction of corporate bankruptcy. The Journal of Finance, 23(4), 589-609. doi:10.1111/j.1540-6261.1968.tb00843.x

Altman, E.I., Iwanicz-Drozdowska, M., Laitinen, E.K., \& Suvas, A. (2017). Financial distress prediction in an international context: A review and empirical analysis of Altman's Z-score model. Journal of International Financial Management \& Accounting, 28(2), 131-171. doi: 10.1111/jifm.12053 
Andreeva, G., Calabrese, R., \& Osmetti, S.A. (2016). A comparative analysis of the UK and Italian small businesses using Generalised Extreme Value models. European Journal of Operational Research, 249(2), 506-516. doi: 10.1016/j.ejor.2015.07.062

Andrikopoulos, P., \& Khorasgani, A. (2018). Predicting unlisted SMEs' default: Incorporating market information on accounting-based models for improved accuracy. The British Accounting Review, 50(5), 559-573. doi: 10.1016/j.bar.2018.02.003

Apergis, N., Bhattacharya, M., \& Inekwe, J. (2019). Prediction of financial distress for multinational corporations: Panel estimations across countries. Applied Economics, 51(39), 4255-4269. doi: 10.1080/00036846.2019.1589646

Audretsch, D.B., \& Mahmood, T. (1995). New firm survival: New results using a hazard function. The Review of Economics and Statistics, 77(1), 97-103. doi: 10.2307/2109995

Beaver, W.H. (1966). Financial ratios as predictors of failure. Journal of Accounting Research, 4, 71-111. doi: $10.2307 / 2490171$

Blanco, A., Irimia, A., \& Oliver, M.D. (2012). The prediction of bankruptcy of small firms in the UK using logistic regression. Análisis Financiero, 118, 32-40.

Calabrese, R., Marra, G., \& Osmetti, S.A. (2016). Bankruptcy prediction of small and medium enterprises using a flexible binary generalized extreme value model. Journal of the Operational Research Society, 67(4), 604-615. doi: $10.1057 /$ jors. 2015.64

Chappell, N., \& Jaffe, A. (2018). Intangible investment and firm performance. Review of Industrial Organization, 52(4), 509-559. doi: 10.1007/s11151-018-9629-9

Charitou, A., Neophytou, E., \& Charalambous, C. (2004). Predicting corporate failure: Empirical evidence for the UK. European Accounting Review, 13(3), 465-497. doi: 10.1080/0963818042000216811

Cultrera, L., \& Brédart, X. (2016). Bankruptcy prediction: The case of Belgian SMEs. Review of Accounting and Finance, 15(1), 101-119. doi: 10.1108/RAF-06-2014-0059

Elston, J.A., \& Audretsch, D.B. (2011). Financing the entrepreneurial decision: An empirical approach using experimental data on risk attitudes. Small Business Economics, 36(2), 209-222. doi: 10.1007/s11187-009-9210-x

Fejér-Király, G. (2015). Bankruptcy prediction: A survey on evolution, critiques, and solutions. Acta Universitatis Sapientiae, Economics and Business, 3(1), 93-108. doi:10.1515/auseb-2015-0006

Gepp, A., \& Kumar, K. (2015). Predicting financial distress: A comparison of survival analysis and decision tree techniques. Procedia Computer Science, 54, 396 - 404. doi:10.1016/j.procs.2015.06.046

Giacosa, E., Halili, E., Mazzoleni, A., Teodori, C., \& Veneziani, M. (2016). Re-estimation of company insolvency prediction models: Survey on Italian manufacturing companies. Corporate Ownership and Control, 14(1), $159-174$. doi: $10.22495 /$ cocv14i1c1p1

Görg, H., \& Strobl, E. (2003). Multinational companies, technology spillovers and plant survival. The Scandinavian Journal of Economics, 105(4), 581-595. doi:10.1111/j.0347-0520.2003.00003.x

Gregova, E., Valaskova, K., Adamko, P., Tumpach, M., \& Jaros, J. (2020). Predicting financial distress of Slovak enterprises: Comparison of selected traditional and learning algorithms methods. Sustainability, 12, 1-17. doi: $10.3390 /$ su12103954

Gupta, J., Barzotto, M., \& Khorasgani, A. (2018a). Does size matter in predicting SMEs failure? International Journal of Finance \& Economics, 23(4), 571-605. doi: 10.1002/ijfe.1638

Gupta, J., Gregoriou, A., \& Ebrahimi, T. (2018b). Empirical comparison of hazard models in predicting SMEs failure. Quantitative Finance, 18(3), 437-466. doi:10.1080/14697688.2017.1307514

Hill, N.T., Perry, S.E., \& Andes, S. (1996). Evaluating firms in financial distress: An event history analysis. Journal of Applied Business Research, 12(3), 60-71.

Jackson, R.H.G., \& Wood, A. (2013). The performance of insolvency prediction and credit risk models in the UK: A comparative study. The British Accounting Review, 45(3), 183-202. doi: 10.1016/j.bar.2013.06.009

Kubíčková, D., \& Nulíček, V. (2016). Predictors of financial distress and bankruptcy model construction. International Journal of Management Science and Business Administration, 2(6), 34-41. doi: 10.18775/ijmsba.1849-56645419.2014.26.1003 
Malakauskas, A., \& Lakstutiene, A. (2021). Financial distress prediction for small and medium enterprises using machine learning techniques. Inzinerine Ekonomika-Engineering Economics, 32(1), 4-14. doi: 10.5755/j01.ee.32.1.27382

Mata, J., \& Portugal, P. (1994). Life duration of new firms. The Journal of Industrial Economics, 42(3), 227-245. doi: $10.2307 / 2950567$

Mselmi, N., Lahiani, A., \& Hamza, T. (2017). Financial distress prediction: The case of French small and mediumsized firms. International Review of Financial Analysis, 50, 67-80. doi: 10.1016/j.irfa.2017.02.004

Muñoz-Izquierdo, N., Laitinen, E.K., Camacho-Miñano, M.-del-M., \& Pascual-Ezama, D. (2020). Does audit report information improve financial distress prediction over Altman's traditional Z-Score model? Journal of International Financial Management \& Accounting, 31(1), 65-97. doi: 10.1111/jifm.12110

Ohlson, J.A. (1980). Financial ratios and the probabilistic prediction of bankruptcy. Journal of Accounting Research, 18(1), 109-131. doi: 10.2307/2490395

Oliveira, M.D.N.T., Ferreira, F.A.F., Ilander, G.O.P.-B., \& Jalali, M.S. (2017). Integrating cognitive mapping and MCDA for bankruptcy prediction in small- and medium-sized enterprises. Journal of the Operational Research Society, 68(9), 985-997. doi: 10.1057/s41274-016-0166-3

Omelka, J., Beranová, M., \& Tabas, J. (2013). Comparison of the models of financial distress prediction. Acta Universitatis Agriculturae et Silviculturae Mendelianae Brunensis, 61(7), 2587-2592. doi: $10.11118 / \operatorname{actaun} 201361072587$

Pacheco, L. (2015). SMEs probability of default: The case of the hospitality sector. Tourism \& Management Studies, 11(1), 153-159.

Pérez, S.E., Llopis, A.S., \& Llopis, J.A.S. (2004). The determinants of survival of Spanish manufacturing firms. Review of Industrial Organization, 25(3), 251-273. doi:10.1007/s11151-004-1972-3

Pervan, I., Pervan, M., \& Kuvek, T. 2018. Firm failure prediction: The financial distress model vs traditional models. Croatian Operational Research Review, 9(2), 269-279. doi: 10.17535/crorr.2018.0021

Pinheiro, T.G. (2019). Industry in Portugal: a sector in motion. Retrieved from: https://www.caixabankresearch.com/en/industry-portugal-sector-motion

Platt, H.D., \& Platt, M.B. (2002). Predicting corporate financial distress: Reflections on choice-based sample bias. Journal of Economics and Finance, 26(2), 184-199. doi:10.1007/BF02755985

Pozzoli, M., \& Paolone, F. (2016). An overlook at bankruptcy prediction in Italy in 2016: An application of the Altman's model on failed Italian manufacturing companies in the 2016-first quarter. International Journal of Accounting and Financial Reporting, 6(2), 293-309. doi:10.5296/ijafr.v6i2.10339

Quintiliani, A. (2017). The costs of SME's financial distress: A cross-country analysis. Rivista Piccola Impresa/Small Business, 3, 71-92. doi: 10.14596/pisb.284

Šarlija, N., \& Jeger, M. (2011). Comparing financial distress prediction models before and during recession. Croatian Operational Research Review, 2(1), 133-142.

Succurro, M., \& Mannarino, L. (2014). The impact of financial structure on firms' probability of bankruptcy: A comparison across Western Europe convergence regions. Regional and Sectoral Economic Studies, 14(1), 81-94.

Tascón, M.T., \& Castaño, F. J. (2017). Selection of variables in small business failure analysis: Mean selection vs. median selection. Revista de Metodos Cuantitativos para la Economia y la Empresa, 24, 54-88.

Vavřina, J., Hampel, D., \& Janová, J. (2013). New approaches for the financial distress classification in agribusiness. Acta Universitatis Agriculturae et Silviculturae Mendelianae Brunensis, 61(4), 1177-1182. doi:10.11118/actaun201361041177

Yazdanfar, D., \& Nilsson, M. (2008). The bankruptcy determinants of Swedish SMEs. Institute for Small Business \& Entrepreneurship, 5-7(2008), 1-14.

Žiković, I.T. (2018). Challenges in predicting financial distress in emerging economies: The case of Croatia. Eastern European Economics, 56(1), 1-27. doi:10.1080/00128775.2017.1387059

Zmijewski, M.E. (1984). Methodological issues related to the estimation of financial distress prediction models. Journal of Accounting Research, 22, 59-82. doi: 10.2307/2490859. 